\title{
Article
}

\section{A preliminary examination of differential decomposition patterns in mass graves}

\author{
Troutman, Lauren, Moffatt, Colin and Simmons, Tal Linda Ileen \\ Available at http://clok.uclan.ac.uk/3309/ \\ Troutman, Lauren, Moffatt, Colin and Simmons, Tal Linda lleen (2014) A \\ preliminary examination of differential decomposition patterns in mass \\ graves. Forensic Science International, 59 (3). pp. 621-626. ISSN 0379-0738
}

It is advisable to refer to the publisher's version if you intend to cite from the work.

For more information about UCLan's research in this area go to

http://www.uclan.ac.uk/researchgroups/ and search for < name of research Group>.

For information about Research generally at UCLan please go to

http://www.uclan.ac.uk/research/

All outputs in CLoK are protected by Intellectual Property Rights law, including Copyright law. Copyright, IPR and Moral Rights for the works on this site are retained by the individual authors and/or other copyright owners. Terms and conditions for use of this material are defined in the policies page.

\section{CLoK}

Central Lancashire online Knowledge www.clok.uclan.ac.uk

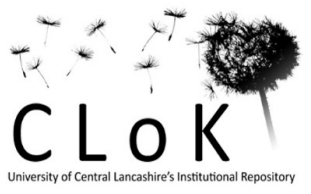




\section{Elsevier Editorial System(tm) for Forensic Science International Manuscript Draft}

\section{Manuscript Number: FSI-D-12-00060R1}

Title: A preliminary examination of differential decomposition patterns in mass graves

Article Type: Original Research Paper

Keywords: Forensic science, taphonomy, mass graves, decomposition, accumulated degree days, burial depth

Corresponding Author: Dr Tal Simmons, PhD

Corresponding Author's Institution: University of Central Lancashire

First Author: Lauren Troutman, MSc

Order of Authors: Lauren Troutman, MSc; Colin Moffatt, PhD; Tal Simmons, PhD

Abstract: This study represents a preliminary, quantitative approach to the examination of differential decomposition patterns in mass graves. Five pairs of mass graves, each containing the carcasses of 21 rabbits, were used to examine decomposition extent at four fixed positions within the burial. A pair of graves was exhumed at approximately 100 accumulated degree day (ADD) intervals. At exhumation the total body score (TBS) and internal carcass temperature of each rabbit were recorded. Although there was no significant difference between decomposition extent for core and deep-positioned carcasses $(p=0.13)$, all other position differences were significant $(p<0.001)$. Decomposition occurred fastest in shallow carcasses, followed by mid-outer carcasses; both deep and core carcasses exhibited a lesser extent. Internal carcass temperature was significantly influenced by carcass location within the mass grave $(\mathrm{p}<0.001)$; there was a mean internal temperature difference of ca. $1 \mathrm{oC}$ between deep and shallow carcasses (30 cm apart). Adipocere formation was minimal and confined, with the exception of a single individual in the mid- periphery, to the deepest level. Decomposition extent may be as affected by the compactness of a mass as by interment depth and/or peripheral substrate contact, and further investigation into the role of oxygenation is required.

Suggested Reviewers: 
A preliminary examination of differential decomposition patterns in mass graves

Lauren Troutman, MSc, Colin Moffatt, PhD and Tal Simmons, PhD

School of Forensic and Investigative Sciences

University of Central Lancashire

Preston PR1 2HE

Running Head: Differential decomposition patterns in mass graves 


\section{Abstract:}

2 This study represents a preliminary, quantitative approach to the examination of differential

3 decomposition patterns in mass graves. Five pairs of mass graves, each containing the carcasses

4 of 21 rabbits, were used to examine decomposition extent at four fixed positions within the

5 burial. A pair of graves was exhumed at approximately 100 accumulated degree day (ADD)

6 intervals. At exhumation the total body score (TBS) and internal carcass temperature of each

7 rabbit were recorded. Although there was no significant difference between decomposition

8 extent for core and deep-positioned carcasses $(p=0.13)$, all other position differences were

9 significant $(p<0.001)$. Decomposition occurred fastest in shallow carcasses, followed by mid-

10 outer carcasses; both deep and core carcasses exhibited a lesser extent. Internal carcass

11 temperature was significantly influenced by carcass location within the mass grave $(p<0.001)$;

12 there was a mean internal temperature difference of ca. $1^{\circ} \mathrm{C}$ between deep and shallow

13 carcasses (30 cm apart). Adipocere formation was minimal and confined, with the exception of

14 a single individual in the mid-periphery, to the deepest level. Decomposition extent may be as

15 affected by the compactness of a mass as by interment depth and/or peripheral substrate

16 contact, and further investigation into the role of oxygenation is required.

20 Key Words:

21 Forensic science, taphonomy, mass graves, decomposition, accumulated degree days, burial 22 depth 


\section{Introduction}

24 The application of taphonomy to the investigation of mass graves provides assistance in

25 establishing context and reconstructing a broad sequence of events to achieve the ultimate goal

26 of victim identification [1, 2]. One fundamental aspect of such investigations is to establish the

27 post mortem interval (PMI) for remains within the grave and document associated taphonomic

28 evidence $[3,4]$ in order to corroborate witness statements, limit the number suspects involved,

29 link the grave to a particular event or perpetrator and increase chances of positive identification

30 [4]. Although several researchers (e.g. [5], [6], [7],[8]) have published accounts pertaining to

31 mass grave exhumations, classification systems [9], and guidelines/strategies for excavation and

32 maximisation of data retrieval $[10,11,12,13,14]$, data concerning the decomposition rate,

33 extent and pattern of remains within mass graves are scant, and experimental approaches to

34 the issue have not been undertaken.

35 Accurate PMI estimations are generally based on degree of soft tissue decomposition,

36 identifiable stages of tissue alteration and loss that occur in a predictable, sequential and semi-

37 continuous pattern at a rate that is dependent on both accumulated temperature over time

38 (measured in Accumulated Degree Days (ADD)) $[15,16]$ and insect access $[17,18,19]$. ADD

39 constitutes the accumulation of thermal energy (degrees Celsius) over time (days) and is related

40 to the rate of the chemical and biological processes of decomposition $[19,20,21]$.

41 Characteristic features of decomposition have been categorized into phases for the purpose of

42 soft tissue taphonomy [22], most recently by Megyesi et al. [15] and previously by Reed [23],

43 Payne [24], Johnston [25] and Galloway et al. [26]. Megyesi et al. [15] assigned numerical values

44 to three anatomical regions (head and neck, abdomen and limbs) by visually evaluating the 
45 state of decomposition according to macroscopic criteria. These values are summed to

46 generate a Total Body Score (TBS) that is used to predict Accumulated Degree Days (ADD),

47 which, in turn, provides an accurate and reliable method of estimating the PMI [15].

48 Buried remains however, generate unique microenvironments quite different to those of surface

49 remains with consequences for the rate and pattern of decomposition; the interactions of

50 various biological, geological and environmental variables (i.e. temperature, insect access,

51 surrounding substrate, etc.) results in a slower rate of decomposition. When such biological,

52 geological and environmental factors are eliminated and temperature remains relatively

53 constant, decomposition of buried remains is frequently stated to take approximately eight

54 times as long $[15,27,28,29,30]$. This delay is primarily attributed to the limitation of insect

55 access (which eliminates insect-mediated degradation of soft tissue) and ambient

56 temperature. Simmons et al. $[18,19]$ demonstrated that where insects can freely access a

57 carcass, decomposition progresses faster than where they are excluded by any mechanism,

58 whether indoors, in water, or buried. Likewise, the speed at which decomposition progresses

59 increases as temperature rises. The mechanism by which this occurs is through the metabolic

60 activity of micro-organisms in soil; as temperature of the soil decreases, so does the rate that

61 cellular processes occur within the microbial cells, retarding microbial activity and ultimately,

62 decomposition [30, 31]. Fiedler and Graw [27] note greater interment depths can produce a

63 cooling effect resulting in lower internal burial temperatures contributing to a reduced rate of

64 decomposition in deeply buried remains. Simmons et al. $[17,18,19]$ demonstrated that

65 decomposition (as measured by TBS) is strongly correlated with the accumulation of soil 
66 temperature at burial depth, and ADD predictive equations can be produced for burials (with

67 and without insect access) in addition to surface remains.

68 The nature of the surrounding also soil bears influence on the rate and pattern of

69 decomposition. Moisture rich or wetter environments are conducive to adipocere formation,

70 well drained or dry soils can promote mummification, and extreme soil acidity or alkalinity has

71 been reported to decrease microbiological activity and, subsequently, decomposition [31, 32,

72 33]. Soil moisture, modified by the soil texture and structure, is understood to control microbial

73 motility, the diffusion of nutrients and waste, and the activity of extracellular enzymes [28].

74 Where the host soil environment exhibits moisture content which exceeds optimal matric

75 potential (suction with which water is held between soil particles) decomposition processes can

76 be retarded [28]. Moreover, in areas where soil is poorly drained or seasonally waterlogged

77 (wetter soils), levels of free oxygen are low and gas diffusion is slower, limiting microbial activity

78 resulting in low bioactivity $[16,28,32,34]$.

79 Though there is published literature pertaining to decomposition rate of buried remains [17,

$8018,30,35]$ with and without insect access [17, 36], the majority of the literature concerning

81 mass graves is instead primarily focused upon excavation technique $[10,11,12,13,14]$.

82 Although Haglund [5] considers the taphonomic properties of mass burials, a comprehensive,

83 quantitative examination of how decomposition processes differ within mass graves has not

84 been satisfactorily undertaken since Mant's [37] initial work.

85 Mass graves have been most recently defined as a single burial unit containing two or more

86 victims who have died as a result of extra-judicial, summary or arbitrary executions [9] and are

87 characterized by two main components: a body mass and a periphery. The body mass consists 
88 of bodies which are only in contact with one another and often forms a dense contiguous

89 aggregate, whereas the periphery is a zone comprised of bodies in contact with both the mass

90 and the surrounding substrate $[5,33,37]$.

91 Mass graves present a unique micro-environment where decomposition differs from single

92 burials, as a number of bodies within a single grave unit can result in complex interactions

93 among a wide range of variables (i.e. climate, depth, oxidisation, soil environment, hydrology,

94 clothing, size/weight individuals) [38]. Mant [37], who exhumed 150 World War II graves in

95 North West Europe, reported that bodies decomposed at various rates within a mass grave

96 based on their relative position to the body mass; bodies positioned towards the centre mass

97 decomposed at a slower rate than those towards the periphery $[33,37]$. This differential

98 decomposition/preservation, a phenomenon termed the "feathered edge effect" [37], has been

99 attributed to the unique taphonomic microenvironments which are created in such

100 circumstances. According to Haglund [5], the peripheral bodies bridge two taphonomic

101 interfaces (i.e. the bodies of the mass and surrounding substrate) and are affected by the

102 porosity and percolation of the soil. Conversely, bodies of the mass generate their own

103 synergistic environment, separate from that of the soil [5]. This phenomenon however, remains

104 largely anecdotal and there is a little in the published literature to wholly confirm its presence,

105 the degree of differential appearance and the frequency of occurrence.

106 The aim of this research was to conduct a preliminary experiment, to determine whether the

107 position of a carcass within a mass grave affects its extent of decomposition over time.

108 Consistent with what Mant [33, 37] proposed, it was hypothesized that there would be a

109 significant difference in the extent of decomposition over time between carcasses situated in 
110 various positions within the grave. In particular, it was predicted that carcasses positioned more

111 superficially and along the periphery would decompose to a greater extent than those

112 positioned in the centre of the mass (surrounded only by other carcasses) and those situated

113 deeper along the periphery.

114

\section{Materials and Methods}

116 This research was conducted at the University of Central Lancashire's TRACES ('Taphonomic

117 Research in Anthropology: Centre for Experimental Studies') facility, located in Northwest

118 England. TRACES consists of 13 acres of semi-improved grade 3 rough pastureland surrounded

119 by a thin mixed native tree line and is situated approximately $270 \mathrm{~m}$ above average mean sea

120 level [39]. The soil is approximately $50 \mathrm{~cm}$ of slow-permeable, wet upland soil over clay and

121 milnow sandstone that supports vegetation of wet unimproved pasture [40].

122 A total of 210 wild rabbits (Oryctolagus cuniculus), with an average weight of $1.59 \mathrm{~kg}$ and an

123 accrued ADD of 8 since death, were used in this study. The rabbits exhibited projectile trauma

124 resulting from a 12 gauge shotgun with which they were culled, the most common type of

125 weapon used to hunt rabbits. Detailed information concerning the location the gunshot

126 wounds could not be determined as it would have require removal of the fur and skin.

127 Penetrating trauma and location has been previously shown to have no influence on the extent

128 of decomposition in either surface or buried remains $[33,37,41]$ and gunshot trauma is

129 common within mass graves [8]. Twenty-one rabbits were interred within ten graves

130 (dimensions of each: $60 \mathrm{~cm} \times 60 \mathrm{~cm} \times 60 \mathrm{~cm}$ ). The rabbits were arranged in a circular fashion so

131 as to establish concrete positions, i.e. the location, or position, of a carcass within a mass grave. 
132 The four zones include: Shallow (Periphery - 5 rabbits), Mid-Outer (Periphery - 5 rabbits), Core

133 (Center Mass - 5 rabbits) and Deep (Periphery - 6 rabbits) (Figure 1).

134 The graves were dug manually 48 hours prior to burial in order to facilitate rapid inhumation

135 and avoid pre-burial insect access [17]. All graves had flat bases (to prevent the localized

136 collection of water from rainfall and/or of bodily fluids which may encourage the formation of

137 adipocere in specific locations) and a surface depth of $30 \mathrm{~cm}$ (to inhibit insect access and

138 scavenging for the duration of the experiment). The graves were positioned in a grid formation

139 of five columns and two rows with graves situated two meters apart, generating a total surface

140 area of approximately 10 meters $X 3$ meters. A pair of graves was exhumed at every data

141 collection interval.

142

143 Internal Carcass Temperature

144 The internal carcass temperature of each rabbit was measured in ${ }^{\circ} \mathrm{C}$ upon exhumation. These

145 were manually recorded using a probe thermometer placed immediately into the rabbit's

146 abdomen when it was extracted from the ground.

148 Total Body Score

149 Decomposition was measured by recording Total Body Scores of each rabbit upon exhumation

150 using a refined scale from Bachmann and Simmons [17] for rabbit carcasses. This scale is a

151 modification of White's [42] scale for scoring buried rabbit remains, a revision created from

152 Megyesi et al. [15] and Adlam and Simmons [43]. Numerical values were attributed to the head

153 and neck, abdomen and limbs of each rabbit by visually evaluating the state of decomposition

154 according to macroscopic criteria described by Megyesi et al. [15]. These values were summed 
155 to generate the TBS. Additionally, visual characteristics of decomposition were recorded for 156 each carcass and photographs of every rabbit were taken using a Nikon D80 digital camera.

159 Data Collection

160 The duration of the experiment was determined based on an experiment conducted at a

161 different site with different soil conditions by Bachmann and Simmons [17], where the

162 maximum slope of single rabbit burials' decomposition curve was used to predict

163 skeletonisation at 500 ADD. The average ambient soil temperature in North West England is

16410 으 $[17,42]$ resulting in an expected experimental duration of 50 days. Data were collected

165 from five paired grave exhumations; one pair of graves (i.e. Grave 1A/1B) was exhumed and the

166 carcasses evaluated at each of five data collection points approximately every ten days (100

$167 \mathrm{ADD}$ ). Upon exhumation of the third set of graves (Grave $3 A / 3 B$ ) it was determined that this

168 study would benefit extending the duration of interment for the remaining two sets of graves.

169 Therefore, for the purpose of collecting additional data and allowing for a greater level of

170 decomposition, the timing of the remaining exhumations was extended. Hence the final two

171 pairs of graves (4A and 4B; 5A and 5B) were exhumed 120 ADD and 240 ADD after the

172 exhumation of $3 \mathrm{~A}$ and $3 \mathrm{~B}$, respectively.

173

174 Statistical Analysis

175 All statistical analyses were performed using the open access software R [44]. A mixed-effects

176 model was used to compare Total Body Scores (TBS) of different positions over time using the

177 nlme package [45], and treating TBS as a continuous variable. Internal exhumation temperature 
178 data were found to be non-normally distributed, restricting the possible analyses available, so

179 data were converted to differences from the mean temperature for each exhumation period

180 and non-parametric statistics were generated across all exhumations using the Kruskal-Wallis

181 test. Follow-up pairwise comparisons were performed using Steele's test [46] using the npmc

182 package [47].

184 Results

185 Unfortunately, ADD for the four positions could not be calculated as settling of the carcasses

186 within the mass had caused movement of the dataloggers; instead of the dataloggers recording

187 temperatures within each zone of rabbits, the final positions recorded the temperature between

188 each layer. These data could not be corrected for use in the analysis as it was not possible to

189 ascertain at which point during the experiment the loggers ceased to record correctly with

190 regard to their initial position. As a result, the following analyses are based solely on the

191 relationship of TBS to day since burial.

192 There was a marked levelling off of Total Body Scores after the penultimate sampling period, so

193 the final period (Day 64) was not included in this analysis. This produced a model which fit the

194 data sufficiently well, as indicated by diagnostic plots, despite the suggestion of a sigmoid

195 pattern (Figure 3). The mixed-effects model showed a clear relationship between TBS and day

196 across all grave positions $(t=17.4, d f=6, p<0.001)$ with a unit increase in TBS taking 3.45 days.

197 There was no significant difference between the decomposition extent in the core- and the

198 deep positioned carcasses $(t=1.53, d f=154, p=0.13)$, but all other differences were highly

199 significant ( $p<0.001$ in each case). As Figure 2 reflects, decomposition was fastest in shallow 
carcasses, followed by mid-outer carcasses with the deep and core carcasses showing the lesser

201 extent.

202

203 There were significant differences amongst the internal temperatures of rabbits at different

204 positions (Kruskal-Wallis: $\chi^{2}=121, \mathrm{df}=4, \mathrm{p}<0.001$ ). While there was no difference between the

205 core and outer middle position temperatures (Steel's Test: $p=0.999$ ), there were significant

206 differences between all other pairs of positions ( $p<0.001$ in every case). Figure 3 (lower axis)

207 illustrates that the shallower carcasses were at a higher temperature $($ mean difference $=0.58$

$208{ }^{\circ} \mathrm{C}$ ) and the deeper carcasses at a lower temperature (mean difference $=0.56{ }^{\circ} \mathrm{C}$ ) than those of

209 the middle layer (whose values are combined for parsimony). There was a mean temperature

210 difference of a little over $1{ }^{\circ} \mathrm{C}$ between the deep and shallow carcasses, a distance of

211 approximately $30 \mathrm{~cm}$. Thus, the location of a carcass within a mass grave made a significant

212 difference to internal carcass temperature $(p<0.001)$.

213

\section{Discussion}

215 While the results suggest that position of a carcass within a mass grave can influence its extent

216 of decomposition, there appears to be more than one environmental factor influencing this. The

217 more rapid decomposition at the top of the grave was expected, since temperature is a main

218 driver of decomposition [27, 34, 48, 49, 50,51] and carcasses nearer the surface experienced

219 higher temperatures than those beneath. However, differences were found in decomposition

220 extent of deeper carcasses buried at the same depth and at similar temperatures between

221 those at the periphery and those in the centre. This phenomenon has been noted before by

222 others, e.g. Haglund [5]. Furthermore, carcasses that experienced different temperatures (e.g. 
223 those deepest or in the mass centre) actually showed similar extents of decomposition. Clearly,

224 factors other than temperature must be responsible for these discrepancies.

225 We speculate that the amount of oxygen available to the carcasses may be important to the

226 extent of decomposition (and we intend to follow this up with experimental investigation in the

227 near future). For other types of biological matter, it has long been held that decomposition

228 occurs faster in an aerobic environment $[52,53]$. It seems reasonable to suggest that oxygen

229 availability would have been greater with proximity to the soil surface and without other

230 carcasses lying intermediate. At the shallowest layer, carcasses are subject to the percolation of

231 air and water through the superficial layer and/or surrounding substrate $[5,54]$. Moreover, the

232 periphery of the middle layer tends to be less densely compacted than those of the deep layer.

233 Compactness of both soil and carcasses coupled with the temperature difference would likely

234 inhibit gaseous diffusion and moisture availability which would limit microbial activity and

235 prolong the course of decomposition therefore, better preserving the remains $[16,28,31,34$,

$23650,51]$. This is consistent with the results presented here, where more decomposition was seen

237 in the periphery of the middle layer than in either the centre of the middle layer or the entirety

238 of the layer beneath. Carcasses at the bottom of a mass may become increasingly more

239 compressed and compact, with reduced oxygen and moisture availability resulting in a higher

240 proportion of anaerobic decomposition. While anaerobic conditions have been shown to slow

241 decomposition rates in a number of systems, the interaction between decomposition, body

242 position and oxygen availability in mass graves is unclear and requires further investigation.

243 Moreover, the surrounding substrate may inhibit various organisms' microbiological activities;

244 as the natural limits of bacteria to function in hyper-acidic/alkali environments are met, 
245 microbiological function can be inhibited, resulting in a reduced extent of decomposition and in

246 some cases the formation of adipocere [55]. Small quantities of adipocere formation were

247 observed throughout the duration of this study, most commonly observed at the deepest layer

248 of the mass and on one carcass of the mid-outer periphery. The translocation of the liquefied

249 fat content via gravity and its influence on decomposition $[27,56]$ may result in higher levels of

250 adipocere located deeper within a mass contributing to the lesser extent of decomposition of

251 carcasses situated deeper within a grave. Due to the compact nature of the body mass in

252 comparison to the periphery, which potentially inhibits water entry percolating from above,

253 adipocere formation deeper in the mass is more likely. Nevertheless, given that there were few

254 carcasses (mostly of the deeper layer, one of the mid-outer periphery) exhibiting adipocere

255 formation, this speculation requires further experimental observation.

256

\section{Conclusions}

258

259 This study took a preliminary, quantitative approach to the examination of differential

260 decomposition patterns in mass graves, a grey area in the realm of forensic anthropology with

261 few experimentally supported findings and some largely anecdotal reports. Results revealed

262 that decomposition proceeds differentially over time depending on the position of a carcass

263 within a mass; carcasses which were situated in the centre mass and/or deeper within the grave

264 were revealed to decompose to a lesser extent compared to those situated along the periphery

265 and/or more shallow within the grave. These findings confirm current assumptions reported in

266 academic literature. The core mass did decompose to a lesser extent than the peripheral

267 carcass excluding those of the deepest layer (feathered edge effect), suggesting that 
268 decomposition extent may be as affected by compactness of a mass as interment depth and/or

269 peripheral substrate contact. These observations hold implications of a preliminary nature for

270 investigations involving the exhumation of mass graves. Further research that considers the

271 effect of oxygen access and compactness of a mass will be beneficial in advancing an

272 experimentally supported understanding of decomposition processes within mass graves. 


\section{References Cited}

[1] M. Doretti, C. Snow, Forensic anthropology and human rights: the Argentine experience, in: D.W. Steadman (Ed.), Hard Evidence: Case Studies in Forensic Anthropology, Prentice Hall, New Jersey, 2003.

[2] K. Burns, Forensic anthropology and human rights issue, in: K.J. Reichs (Ed.), Forensic Osteology: Advances in the Identification of Human Remains, second edition, Charles C. Thomas, Illinois, 1998.

[3] M. Kaliszan, R. Hauser, G. Kernbach-Wighton, Estimation of the time of death based on the assessment of post mortem processes with emphasis on body cooling, Leg. Med. 11 (2009) 111-117.

[4] P. Sledzik, Forensic taphonomy: postmortem decomposition and decay, in: K.J. Reichs (Ed.), Forensic Osteology: Advances in the Identification of Human Remains, second edition, Charles C. Thomas, Illinois, 1998.

[5] W. Haglund, Recent Mass Graves, An Introduction, in: W. Haglund, M. Sorg (Eds.), Advances in Forensic Taphonomy: Method, Theory and Archaeological Perspectives, CRC Press LLC, London, 2002.

[6] W.D. Haglund, M. Connor, D.D. Scott, The archaeology of contemporary mass graves, Hist. Arch., 35 (2001) 57-69.

[7] S. Cordner, R. Coupland, Missing people and mass graves in Iraq, Lancet, 362 (2003) 13251326. 
[8] Baraybar, J, Pablo, M. Gasior, Forensic anthropology and the most probable cause of death in cases of violations against international humanitarian law: an example from Bosnia and Herzegovina, J. For. Sci., 51(2006) 103-108.

[9] E. Jessee, M. Skinner, A typology of mass grave-related sites, For. Sci. Int. 152 (2005) 55-59.

[10] C. Steele, Archaeology and the forensic investigation of recent mass graves: ethical issues for a new practice of archaeology. Archaeologies: J. Wor. Arch. Cong. 4 (2008) 414-428.

[11] M. Cox, A. Flavel, I. Hanson, J. Laver, R. Wessling (Eds.) The Scientific Investigation of Mass Graves: Towards Protocols and Standard Operating Procedures, Cambridge University Press, Cambridge, 2007.

[12] H. Tuller, M. Duric, Keeping the pieces together: comparison of mass grave excavation methodology, J. For. Sci. 156 (2006) 192-200.

[13] M. Skinner, J. Sterenberg, Turf wars: authority and responsibility for the investigation of mass graves, For. Sci. Int. 151 (2005) 221-232.

[14] M. Skinner, D. Alemppijevic, M. Djuric-Srejic, Guidelines for the international forensic bioarchaeology monitors of mass grave exhumations, For. Sci. Int.134 (2003) 81-92.

[15] M. Megyesi, S. Nawrocki, N. Haskell, Using accumulated degree days to estimate the postmortem interval from decomposed human remains, J. Forensic Sci. 50 (2005) pp. 618626.

[16] A. Vass, W. Bass, J. Wolt, J. Foss, J. Ammons, Time since death determinations of human cadavers using soil solution, J. For. Sci. 37 (1992) 1236-1253. 
[17] J. Bachmann, T. Simmons, The influence of pre-burial insect access on the decomposition rate, J. For. Sci. 55 (2010) 893-900.

[18] T. Simmons, P. Cross, R. Adlam, C. Moffatt, The influence of insects on decomposition rate in buried and surface remains, J. For. Sci. 55 (2010) 889-892.

[19] T. Simmons, R. Adlam, C. Moffat, Debugging decomposition data: comparative taphonomic studies and the influence of insects and carcass size on decomposition rate, J. For. Sci. 55 (2010) 8-13.

[20] C.Y Arnold, The determination and significance of the base temperature in a linear heat unit system, P. Am. Soc. Hortic. Sci. 74 (1959) 430-445.

[21] C.Y Arnold, Maximum-minimum temperatures as a basis for computing heat units, P. Am. Soc. Hortic. Sci. 76 (1960) 682-692.

[22] M. Micozzi, Postmortem Changes in Human and Animal Remains, Charles C. Thomas, Illinois, 1991.

[23] H. Reed, A study of dog carcass communities in Tennessee, with special reference to the insects, American Midland Naturalist, 59 (1958) 213- 245.

[24] J. Payne, A summer carrion study of the baby pig Sus scrofa Linnaeus, Ecology, 46 (1965) 592-602.

[25] D. Johnson, Seasonal and microseral variation in the insect population on carrion, American Midland Naturalist, 93 (1975) 79-90. 
[26] A. Galloway, W.H. Birkby, A.M. Jones, T.E. Henry, B.O. Parks, Decay rates of human remains in an arid environment, J. For. Sci., 34 (1989) 607-616.

[27] S. Fielder, M. Graw, Decomposition of buried corpses, with special reference to the formation of adipocere, Naturwissenschaften, 90 (2003) 291-300.

[28] D.O Carter, D.Yellowlees, M. Tibbett, Moisture can be the dominant environmental parameter governing cadaver decomposition in soil, For. Sci. Int. 200 (2010) 60-66.

[29] J. Dix, M. Graham, Time of Death, Decomposition and Identification: An Atlas, CRC Press, London, 2000.

[30] W. Rodriguez, Decomposition of buried and submerged bodies, in: W. Haglund, M. Sorg (Eds.), Forensic Taphonomy: The Postmortem Fate of Human Remains, CRC Press LLC, London, 1997.

[31] H. Gill-King, Chemical and ultrastructural aspects of decomposition, in: W. Haglund, M. Sorg (Eds.), Forensic Taphonomy: The Postmortem Fate of Human Remains, CRC Press LLC, London, 1997.

[32] B. Turner, P. Wiltshire, Experimental validation of forensic evidence: a study of the decomposition of buried pigs in a heavy clay soil, For. Sci. Int. 101 (1999) 113-122.

[33] A.K. Mant, Knowledge acquired from post-War exhumations, in: A. Boddington, A.N. Garland, R.C. Janaway (Eds.), Death, Decay and Reconstruction: Approaches to Archaeology and Forensic Science, Manchester University Press, Manchester, 1987. 
[34] A.N. Garland, R.C. Janaway, The taphonomy of inhumation burials, in: C.A. Roberts, F. Lee, J.L. Bintliff (Eds.), Burial Archaeology: Current Research, Methods and Developments, British Archaeological Reports, Oxford, 1989.

[35] A.S. Wilson, R.C. Janaway, A.D. Holland, H.I. Dodson, E. Baran, A.M. Pollard, D.J. Tobin, Modelling the buried human body environment in upland climes using three contrasting field sites, For. Sci. Int. 169 (2007) 6-18.

[36] H. Schroeder, H. Klotzbach, K. Püschel, Insects' colonization of human corpses in warm and cold seasons. Leg. Med. 5 (2003) S372-S374.

[37] A.K. Mant, A Study of Exhumation Data, Ph.D. Thesis, London University, 1950.

[38] J. Hunter, M. Cox, Forensic Archaeology: Advances in Theory and Practice, Routledge, New York, 2005.

[39] Earth Tools (Data recorded Feb. 2000) : HYPERLINK "http://www.earthtools.org"http://www.earthtools.org" NASA.

[40] National Soil Resources Institute, Cranfield University: HYPERLINK "http://www.landis.org.uk/soilscapes/"http://www.landis.org.uk/soilscapes/".

[41] P. Cross, T. Simmons, The influence of penetrative trauma on the rate of decomposition, J. For. Sci. 55 (2010) 295-301.

[42] R. White, Decomposition in a mass grave and the Implications for Post Mortem Interval Estimate, Proceedings of the American Academy of Forensic Sciences, Annual Meeting, San Antonio, TX, February 19-24 (2007) 367. 
[43] R. Adlam, T. Simmons, The effect of repeat physical disturbance on soft tissue decomposition - are taphonomic studies an accurate reflection of decomposition, J. For. Sci., 52 (2007) 1007-1014.

[44] R Development Core Team (2010). R: A language and environment for statistical computing, R Foundation for Statistical Computing, Vienna, Austria. ISBN 3-900051-07-0, URL http://www.R-project.org/.

[45] J. Pinheiro, D. Bates, S. DebRoy, D. Sarkar and the R Development Core Team, nlme: Linear and Nonlinear Mixed Effects Models. R package version 3. 1-97, 2010.

[46] R. D. G. Steel, A rank sum test for comparing all pairs of treatments, Technometrics 2 (1960) 197-207.

[47] J. Helms, U. Munzel, npmc, Nonparametric Multiple Comparisons, R package version 1. 0-7, 2008.

[48] A. Vass, S.A. Barshick, G. Sega, J. Caton, J.T. Skeen, J.C. Love, J.A. Synstelien, Decomposition chemistry of human remains: a new methodology for determining the postmortem interval. J. For. Sci. 47 (2002) 542-553.

[49] R. Mann, W. Bass, L. Meadows, Time since death and decomposition of the human body: variables and observations in case and experimental field studies, J. For. Sci. 35 (1990) 103111.

[50] D.O Carter, M. Tibbett, Microbial decomposition of skeletal muscle tissue (Ovis aries) in a sandy loam soil at different temperatures, Soil Biol. Biochem. 38 (2006) 1139-1145.

[51] D.O Carter, D. Yellowlees, M. Tibbett, Temperature affects microbial decomposition of cadavers (Rattus rattus) in contrasting soils, Appl. Soil Ecol. 40 (2008) 129-137. 
[52] D.J. Greenwood, The effect of oxygen concentration on the decomposition of organic material in soil, Plant and Soil, 4 (1961) 360-376.

[53] E. Kristensen, S.I. Ahmed, A.H. Devol, Aerobic and anaerobic decomposition of matter in marine sediment: which is fastest?, Limnology and Oceanography, 40 (1995) 1430-1437.

[54] A. Vass, Beyond the grave - understanding human decomposition, Microbiology Today, 28 (2001) 190-192.

[55] S.L. Forbes, B.H. Stuart, B.B. Dent, The effect of the burial environment on adipocere formation, For. Sci. Int. 154 (2005) 24-34.

[56] S.L. Forbes, B.H. Stuart, B.B. Dent, The effect of soil type on adipocere formation, For. Sci. Int. 154 (2005) 35-43. 
Additional information and reprint requests:

Tal Simmons, Ph.D.

School of Forensic and Investigative Sciences, University of Central Lancashire, PRESTON, PR1 2HE, U.K.

E-mail: tlisimmons@uclan.ac.uk 


\section{Figure Captions}

Figure 1 . The layers comprising the circular arrangement of carcasses determining the internal grave positions designated in this study: a) Deep b) Mid-Outer c) Core d) Shallow e) TwoDimensional, vertical cross-section representation of grave.

Figure 2. Total body scores for all carcasses against exhumation day (excluding final day - see text) with regression lines.

Figure 3. Mean total body scores (grey) and mean temperatures (black) for grave positions against day of exhumation. In the temperature plot, mid outer and mid inner temperatures have been combined as have their symbols. Points have been offset slightly on Day axis for the sake of ease of interpretation; there were five exhumation days. 

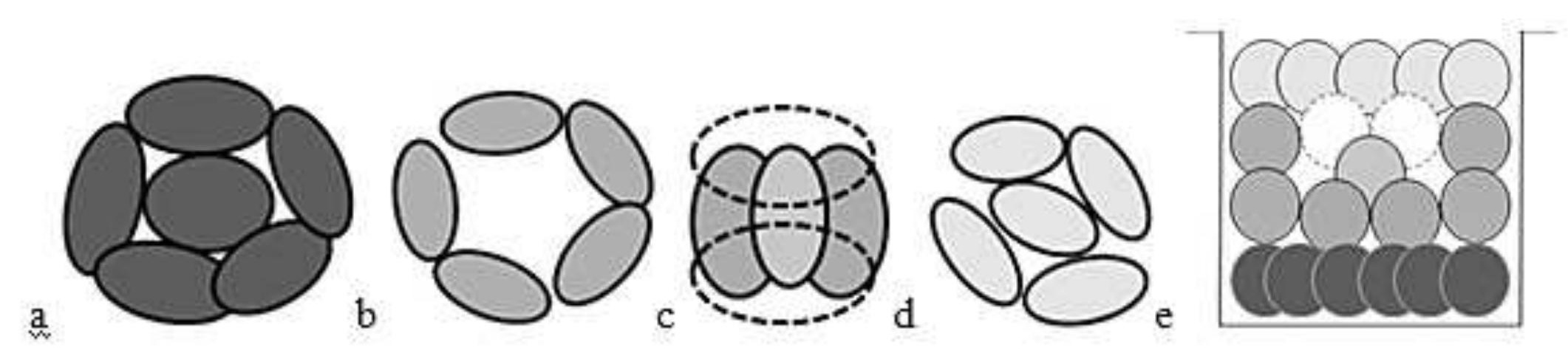

Figure 1

$\stackrel{a}{w}$ 


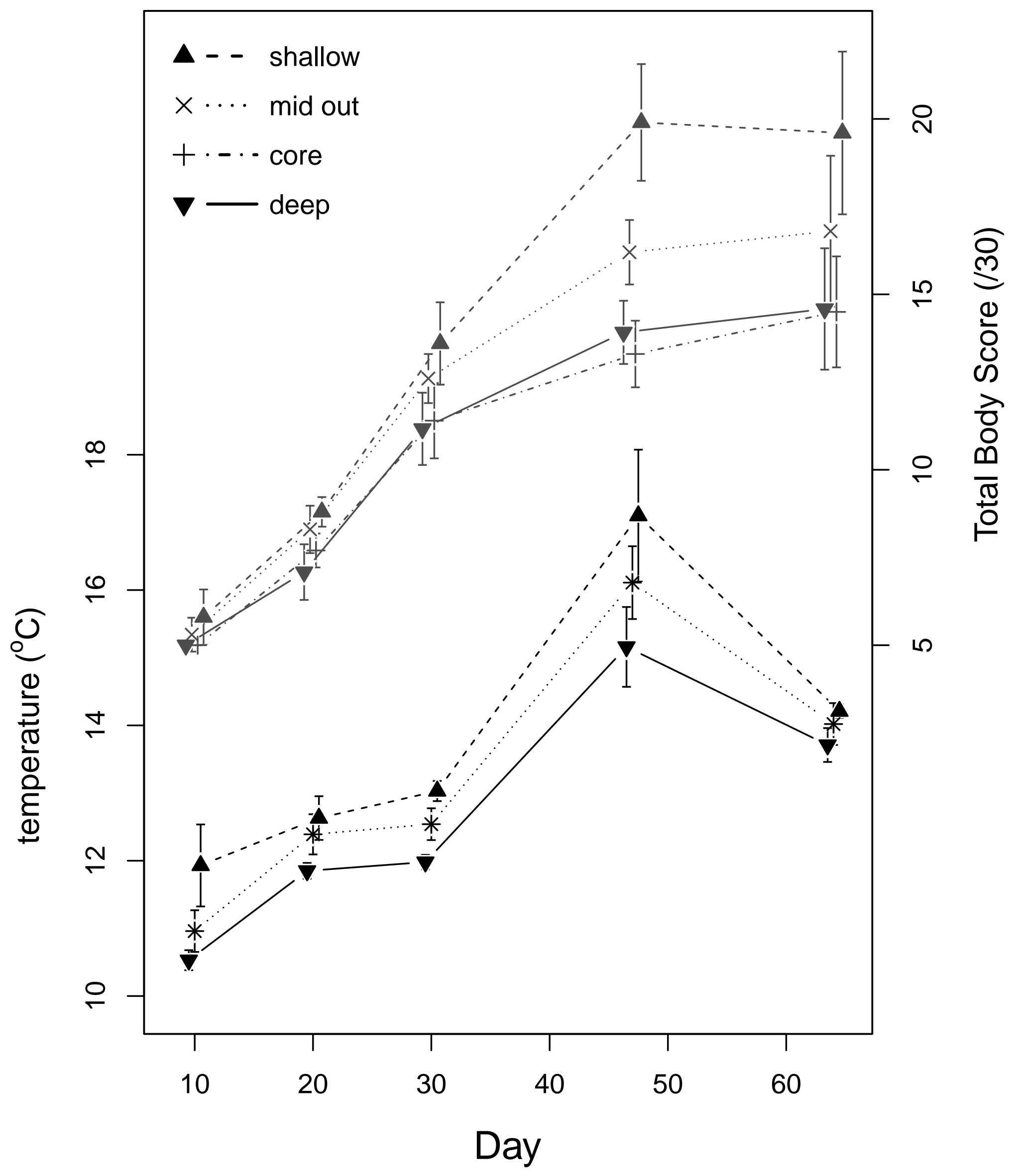




\subsubsection{2}

Dear Editor,

We hereby submit the revisions to Manuscript FSI-D-12-00060R1 in hopes that it now meets the required standard.

We sincerely apologise for the delay in re-submission. Ms Troutman, the senior author, was travelling in South America for much of the intervening time and subsequently suffered a death in the family, so her required input was, of necessity, deferred.

We urge you to review the table below that details how we have met each of the requirements specified in the reviewer's comments. We have done a very thorough job and responded to each one of the specifications made by the reviewer - and I have furthermore noted each line and page number on which the response/correction/explanation can be found within the revised manuscript. It is therefore hoped that you, in your editorial capacity, will find this acceptable without requiring further review and it can be published without further postponement.

With our thanks,

Tal Simmons, Colin Moffatt and Lauren Troutman

The points raised by the reviewer have been addressed as follows:

\begin{tabular}{|l|l|}
\hline Reviewer Comment & How addressed \\
\hline $\begin{array}{l}\text { Please include continuous line numbers } \\
\text { throughout all of your manuscripts. It makes the } \\
\text { review process much more efficient. Also, } \\
\text { include page numbers in the manuscript. }\end{array}$ & This has been done \\
\hline $\begin{array}{l}\text { In the Abstract - Third to last sentence: you } \\
\text { state, "temperature was significantly } \\
\text { influenced." but do not provide a p value. Please } \\
\text { provide a p value or change your terminology. }\end{array}$ & This has been added \\
\hline $\begin{array}{l}\text { Introduction (1st paragraph) - please remove } \\
\text { author names after "Although several } \\
\text { researchers (e.g." They are not necessary with } \\
\text { the FSI citation style. }\end{array}$ & This has been done \\
\hline $\begin{array}{l}\text { Introduction (2nd paragraph) - Citing Simmons et } \\
\text { al. (2010) to describe ADDs is not acceptable. } \\
\text { With the wording of the sentence you need to } \\
\text { cite Arnold's work from 1959 and 1960 - and } \\
\text { please remove "amongst others" or include } \\
\text { citations for the other work you refer to. }\end{array}$ & "amongst others" has been removed \\
\hline \begin{tabular}{l} 
Please identify the "array of interrelated, \\
\hline
\end{tabular} & These have been identified in the text \\
\hline
\end{tabular}




\begin{tabular}{|c|c|}
\hline $\begin{array}{l}\text { synergistic biological and geological variables." } \\
\text { that you refer to. }\end{array}$ & \\
\hline $\begin{array}{l}\text { Although the reference to Casper's Law has been } \\
\text { acknowledged, as you state, recent work shows } \\
\text { that it is not accurate. A corpse in soil does not } \\
\text { necessarily decompose eight times more slowly } \\
\text { than one in open air. Please modify this } \\
\text { sentence. }\end{array}$ & $\begin{array}{l}\text { This has been addressed by rewording lines } 48 \text { - } \\
51 \text {, page } 2\end{array}$ \\
\hline $\begin{array}{l}\text { The sentence that begins "This delay, with ADD } \\
\text { constant," is redundant and poorly worded. } \\
\text { Please modify. }\end{array}$ & This has been re-worded in lines 51-53, page 2 \\
\hline $\begin{array}{l}\text { There exist no datasets to show that autolysis is } \\
\text { the primary driver of buried corpse breakdown. } \\
\text { There are certainly no datasets presented in the } \\
\text { book chapter that you cite for this statement. I } \\
\text { concede that it might be possible for autolysis to } \\
\text { outstrip putrefaction in the early postmortem } \\
\text { period when the internal microbiota are in a lag } \\
\text { phase. But there is no evidence to support the } \\
\text { claim that autolysis results in more } \\
\text { decomposition than internal bacteria during } \\
\text { exponential growth or the stationary phase. In } \\
\text { fact, suggesting such a phenomenon goes } \\
\text { against fundamental principles of the ecology of } \\
\text { decomposition in terrestrial ecosystems: the vast } \\
\text { majority of decomposition is mediated by } \\
\text { organisms, not abiotic processes. }\end{array}$ & $\begin{array}{l}\text { This is clearly a difference of opinion and } \\
\text { remains as such }\end{array}$ \\
\hline $\begin{array}{l}\text { 3rd paragraph - Anaerobic conditions are not } \\
\text { always the result of high levels of carbon dioxide. } \\
\text { Anaerobic simply means a lack of oxygen to be } \\
\text { used as the terminal electron acceptor in the } \\
\text { electron transport chain. Also, you should not } \\
\text { discount an environment of low oxygen } \\
\text { availability; the microaerophilic bacteria can } \\
\text { thrive in these habitats. Again, you cite work that } \\
\text { does not support your statements. Some work } \\
\text { you should be familiar with, that would } \\
\text { represent better citations are: }\end{array}$ & The suggested citations have been duly added \\
\hline $\begin{array}{l}\text { 4th paragraph - The fourth paragraph restates } \\
\text { many of the same points introduced in the third } \\
\text { paragraph. Please merge these two paragraphs }\end{array}$ & This has been done \\
\hline
\end{tabular}




\begin{tabular}{|c|c|}
\hline into one. & \\
\hline $\begin{array}{l}\text { Inhibition of postmortem change is not brought } \\
\text { about by adipocere. Adipocere slows } \\
\text { decomposition and acts as a resource for a } \\
\text { number of bacteria. Also delete the term } \\
\text { "spontaneous". }\end{array}$ & This has been done \\
\hline $\begin{array}{l}\text { Please modify "soils cater to." Perhaps, "soils } \\
\text { promote" instead? }\end{array}$ & This has been done - Line 70, page 3 \\
\hline $\begin{array}{l}\text { Be careful with the term "reduce". I suggest that } \\
\text { you change it to "decrease" to avoid confusion } \\
\text { for readers that will be prompted to think of } \\
\text { oxidation-reduction reactions. }\end{array}$ & This has been done, Line 71 , page 3 \\
\hline $\begin{array}{l}\text { 7th Paragraph - Please describe the "wide range } \\
\text { of variables" among which a mass grave can } \\
\text { function. }\end{array}$ & This has been done - lines $93-4$, page 4 \\
\hline $\begin{array}{l}\text { 8th Paragraph - It is not necessary to tell the } \\
\text { reader that your experiment is "scientifically } \\
\text { robust". Please delete that clause. }\end{array}$ & $\begin{array}{l}\text { The phrase "scientifically robust" has been } \\
\text { removed }\end{array}$ \\
\hline $\begin{array}{l}\text { Materials \& Methods (1st paragraph) - Please } \\
\text { include the soil type. The World Reference Base } \\
\text { classification is probably the most appropriate. }\end{array}$ & $\begin{array}{l}\text { The soil has been described and duly referenced } \\
\text { (lines 120-1, page 5) }\end{array}$ \\
\hline $\begin{array}{l}\text { 2nd Paragraph - You imply that the rabbits were } \\
\text { killed with a gunshot. Please make this explicit } \\
\text { and describe the type of firearm used to kill the } \\
\text { rabbits. Also describe the location of the gunshot } \\
\text { wound. }\end{array}$ & $\begin{array}{l}\text { The weapon has been described in line } 124 \text { and } \\
\text { the reason that wound locations could not be } \\
\text { described has been explained in line } 125-6 \text {, page } \\
5\end{array}$ \\
\hline $\begin{array}{l}\text { Please change "manner" to "cause" in the } 2 \text { nd } \\
\text { sentence. Manner of death has a very strict } \\
\text { definition; gunshot wound is not a manner of } \\
\text { death. }\end{array}$ & $\begin{array}{l}\text { This sentence non longer exists given the re- } \\
\text { wording required above }\end{array}$ \\
\hline $\begin{array}{l}\text { Statistical Analysis - Please change text to state, } \\
\text { "non-parametric statistics were generated." }\end{array}$ & This has been done in line 179 , page 8 \\
\hline $\begin{array}{l}\text { Results ( } 2 \text { nd Paragraph) - You refer to Figure } 2 \text { in } \\
\text { the } 2 \text { nd sentence. Do you not mean Figure } 3 \text { ? }\end{array}$ & This has been corrected to read "Figure 3" \\
\hline $\begin{array}{l}\text { Please change all references to the calculation of } \\
\text { rate of decomposition. You did not measure a } \\
\text { rate, which is a function of time. You measured }\end{array}$ & $\begin{array}{l}\text { All references to this experiment studying } \\
\text { decomposition "rate" removed, replaced with } \\
\text { reference to "extent of decomposition" }\end{array}$ \\
\hline
\end{tabular}




\begin{tabular}{|c|c|}
\hline $\begin{array}{l}\text { the extent of decomposition at a series of times. } \\
\text { Rather than say carcasses showed the "slowest } \\
\text { rate" you must say that carcasses "decomposed } \\
\text { less". }\end{array}$ & \\
\hline $\begin{array}{l}\text { In the last sentence of the Results you state "The } \\
\text { location of a carcass within a mass grave made a } \\
\text { significant difference." Please include a p value } \\
\text { or modify this sentence. }\end{array}$ & The $p$-value has been included in line 211 , page 9 \\
\hline $\begin{array}{l}\text { Discussion - The Discussion presents several } \\
\text { problems. Chief of which is that it provides more } \\
\text { evidence to show that you are not familiar with } \\
\text { the literature relevant to your study. You } \\
\text { speculate that the presence of oxygen may be } \\
\text { important to the rate of decomposition. This is } \\
\text { fair, but you should be familiar with this work } \\
\text { because it addresses many of your points. You } \\
\text { also speculate about the role of pH in } \\
\text { decomposition but fail to cite the following } \\
\text { work. }\end{array}$ & $\begin{array}{l}\text { Some of the requested references have been } \\
\text { duly cited }\end{array}$ \\
\hline $\begin{array}{l}\text { You state, "In aerobic conditions respiration, } \\
\text { synthesis of microbial material and rapid } \\
\text { disappearance of simple organic compounds } \\
\text { represents decomposition." This is true but } \\
\text { these processes also occur during anaerobic } \\
\text { respiration. It is not until fermentation is } \\
\text { reached that the components of this sentence } \\
\text { will change. Again, you refer to anoxic conditions } \\
\text { without considering low-oxygen conditions. You } \\
\text { must do so. }\end{array}$ & $\begin{array}{l}\text { This paper is a preliminary investigation in to the } \\
\text { differential decomposition within mass graves, it } \\
\text { was never intended, nor presented, to be a } \\
\text { conclusive discussion of this phenomenon. We } \\
\text { indicate on page } 10 \text {, lines } 225-6 \text {, that this will be } \\
\text { investigated in the future. As } 02 \text { levels were not } \\
\text { measured in our experiment, we really cannot } \\
\text { comment further on this at the present time. }\end{array}$ \\
\hline $\begin{array}{l}\text { One area of the Discussion that is clearly missing } \\
\text { is the modification of the duration of your } \\
\text { experiment. You wisely based the duration of } \\
\text { your experiment on previous datasets generated } \\
\text { at TRACES. Well done. However, those data did } \\
\text { not seem to give you an accurate timeframe and } \\
\text { your experiment had to be extended. Why was } \\
\text { this? Why were the previous datasets not } \\
\text { accurate? What implications do this have on PMI } \\
\text { estimates using data from the TRACES facility? } \\
\text { Without addressing these points it become easy } \\
\text { for a reader to argue that the data are not } \\
\text { reliable. I strongly suggest that you address }\end{array}$ & $\begin{array}{l}\text { This has been discussed earlier in the paper now } \\
\text { on page } 7 \text {, lines } 161-2 \text { re. this being an } \\
\text { experiment at a different location (i.e. not } \\
\text { TRACES) with single burials in different soil } \\
\text { conditions }\end{array}$ \\
\hline
\end{tabular}




\begin{tabular}{|l|l|}
\hline these points and offer logical explanations. & \\
\hline $\begin{array}{l}\text { Conclusions - You again refer to the rate of } \\
\text { decomposition without actually measuring a } \\
\text { rate. Please modify this sentence. Overall, the } \\
\text { latter half of your Conclusion section is not } \\
\text { comprehensible. What does the "entirety" of the } \\
\text { periphery represent? I am not sure how your } \\
\text { results "both challenge and confirm" current } \\
\text { assumptions. To me it appears as though your } \\
\text { findings confirm previous work. }\end{array}$ & $\begin{array}{l}\text { The phrase "entirety of the periphery" has been } \\
\text { removed and re-phrased (see line 263, page 11) } \\
\text { been removed to indicate "confirm" (line 264, } \\
\text { page 11) }\end{array}$ \\
\hline $\begin{array}{l}\text { References - Citation 16 has an incorrect title. } \\
\text { Please provide the correct title. }\end{array}$ & This has been corrected \\
\hline $\begin{array}{l}\text { Figure Legends - It is not appropriate to include } \\
\text { "see text" in a figure legend. A figure legend } \\
\text { must be able to stand alone without the } \\
\text { manuscript text. A reader must be able to } \\
\text { understand the nature of the experiment, its } \\
\text { protocol, and the figure by reading a figure } \\
\text { legend. As such, figure legends typically do not } \\
\text { have a word limit. Please make your figure } \\
\text { legends robust and include the details of your } \\
\text { experiment in each one. }\end{array}$ & $\begin{array}{l}\text { The phrase "see text" has been removed - the } \\
\text { figure legends can stand alone s they were } \\
\text { without this phrase. }\end{array}$ \\
\hline
\end{tabular}

